\title{
Development of digital ventilator with the internet of things for preparation of the next outbreak in Indonesia
}

\author{
Dimas Adiputra* ${ }^{*}$, Isa Hafidz ${ }^{2}$, Billy Montolalu ${ }^{3}$, Fauzan Rasyid ${ }^{4}$ \\ Institut Teknologi Telkom Surabaya, Surabaya, Indonesia ${ }^{1,2,3,4}$
}

\section{Article Info}

Keywords:

Ventilator, Internet of Things, Pressure Control, Website Application, Remote

Monitoring

\section{Article history:}

Received: June 15, 2021

Accepted: July 15, 2021

Published: August 31, 2021

Cite:

Adiputra, D., Hafidz, I., Montolalu, B., \&

Rasyid, F. (2021). Development of Digital

Ventilator with Internet of Things for

Preparation of the Next Outbreak in

Indonesia. Kinetik: Game Technology,

Information System, Computer Network,

Computing, Electronics, and Control, 6(3)

https://doi.org/10.22219/kinetik.v6i3.1281

${ }^{*}$ Corresponding author

Dimas Adiputra

E-mail address:

adimas@ittelkom-sby.ac.id

\begin{abstract}
The emergency of the healthcare device unit, such as a ventilator, has been experienced during the COVID-19 pandemic in 2020. Therefore, ventilator usage is not hard suggested anymore for COVID-19 patients compared to the outbreak beginning. Despite that, it is still essential to have the ventilator ready, if possible, in each house, for the upcoming respiratory syndrome outbreak. Therefore, in this paper, a digital ventilator development is presented. The digital ventilator is comprised of three main parts, such as respiration mechanism (I), controller Internet of Things (IOT) module (II), and website application (III). The developed digital ventilator has been tested by comparing the measurement of respiratory data between the developed digital ventilator and gas flow analyzer. Results show that the respiratory data, such as Pressure Peak (PPeak), Positive End Respiratory Pressure (PEEP), Inspiratory Expiratory Ratio (IE Ratio), Breath per Minute (BPM), and Tidal Volume can be monitored and controlled both directly and online via website application consistently (standard deviation around 10\%) with PPeak absolute error of $1.35 \mathrm{mbar}$, the PEEP absolute error of $0.16 \mathrm{mbar}$. Furthermore, the average time response of the digital ventilator to the input command from the website application is $0.23 \mathrm{~s}$. Therefore, it is safe to assume that the doctor can use the website application to control the digital ventilator remotely.
\end{abstract}

\section{Introduction}

The World Health Organization (WHO) declares COVID-19 as a global pandemic outbreak on March 11, 2020 [1][2][3][4]. The COVID-19 often be categorized with SARS (severe acute respiratory syndrome) and MERS (Middle East respiratory syndrome) since the viruses attack the human respiratory system. The common symptoms are coughing, fever, sneezing, losing taste bud, and losing the smelling ability. The virus can transmit rather easily via the droplet from coughing and sneezing. Even chitchat with the transmitted human can already spread the viruses to the other person. Because of the easy transmission, which is like influenza, the number of COVID-19 victims increased exponentially in the world, including Indonesia [5]. The Indonesian government took the countermeasure to prevent the virus transmission from man to man and decrease cases. The countermeasure is the $3 \mathrm{M}$ policy, which consists of wearing a mask, social distancing, and washing hands regularly [6]. Despite that, the transmission rate is still hardly under control. For instance, the COVID-19 cases number still increased by 14518 cases in late January, after a big scale of social distancing for the past two respective weeks [7].

The victims' number keeps increasing. Some of them are symptomless and can be treated by doing self-isolation for at least 14 days. Meanwhile, the other victims are in an authoritarian state that they need a ventilator for breathing. The number of ventilators available in the hospital cannot cope with the increases of COVID-19 patients, as reported by [8]. If the patient cannot find the much-needed ventilator in the hospital, the patient must be transported to another hospital with an available ventilator. The emergency of health care devices, such as the ventilator, motivates people worldwide to build their ventilators. In Indonesia, the ventilator development has been initiated by universities, such as Institut Teknologi Bandung [9], then followed by Universitas Gadjah Mada [10], and Institut Teknologi Sepuluh November [11]. The goal is to increase the number of ventilator units by developing it so that the ventilator unit number can cope with the COVID-19 cases number.

The ventilator helps the patient to breathe normally by providing mechanical ventilation. There are several ventilation modes in the ventilator, such as full control mode, patient trigger mode, and CPAP mode [12]. The minimum specification of an emergency ventilator for COVID-19 cases is CPAP mode ventilation. In this mode, the constant pressure is given to the lungs, so there is minimum pressure during the expiration, usually called Positive End Expiratory Pressure (PEEP). Maintaining the PEEP helps the COVID-19 patient keep the oxygen a bit longer in the lungs, increasing the probability of absorption by the body. However, later in late 2020, the ventilator is declared unnecessary for COVID-19 patient. The reason is not only the mechanical ventilation can cause lung trauma, but it also increases the humidity inside the COVID-19 patient lung due to the extra oxygen [13]. Then, the moisture causes mucus inside

Cite: Adiputra, D., Hafidz, I., Montolalu, B., \& Rasyid, F. (2021). Development of Digital Ventilator with Internet of Things for Preparation of the Next Outbreak in Indonesia. Kinetik: Game Technology, Information System, Computer Network, Computing, Electronics, and Control, 6(3). https://doi.org/10.22219/kinetik.v6i3.1281https://doi.org/10.22219/kinetik.v6i3.1284 
the lung, which reduced the oxygen absorption instead. The ventilator, which is intended to support the patient respiratory, burdens the respiration process instead. The mucus problem can be solved using a nebulizer to suck the mucus first before respiration interference using the ventilator.

Researchers have developed the use and manufacture of emergency ventilators. The aim of this research is that the makers can easily replicate the tool [14]. Researchers have also developed pneumatic ventilators that can be made cheaply and quickly [15]. In addition, there is also a gas pressure regulator and can be controlled by a mechanical modulator [16][17]. However, the developed emergency ventilators [15][16][17] have limited electronic control challenges in the market. Medical personnel need notifications to find out the function of the device and monitoring patient health.

The ventilator usage is not hard suggested anymore for COVID-19 patients compared to the outbreak beginning because of the pros and cons. Despite that, it is still important to have the ventilator ready, if possible, in each house, for the upcoming respiratory syndrome outbreak. Some patients who do not require ventilators are suggested to do selfisolation because the hospital is fully occupied. However, in case of emergency, patients should also have a ventilator unit in their own house because the hospital is fully occupied. Furthermore, the patient also needs to inform the doctor about their condition when using the ventilator. The pandemic has revolutionized loT management and led to its future application, particularly in E-health [18]. Therefore, a digital ventilator with the Internet of Things (IoT) is developed for this research current and upcoming outbreak. A digital ventilator is created using a component available in the market to be easily replicated later. IOT is also embedded in the developed digital ventilator to be monitored and controlled at a distance through website applications. Therefore, the patient can stay at home while treated by the digital ventilator, and the doctor can do remote monitoring and controlling the patient's respiration using the digital ventilator.

\section{Research Method}

\subsection{Digital Ventilator design}

The digital ventilator consists of three main parts, such as respiration mechanism (I), controller loT module (II), and website application (III), as shown in Figure 1. The developed digital ventilator is a pneumatic type. Although the most popular emergency ventilator is the Ambu bag type [19], the pneumatic type is chosen to be developed because of the ability to control the airflow without an additional hand robot mechanism. Furthermore, fully control mode respiration is adopted because the target patient is a COVID-19 patient in an emergency state unable to breathe by themselves [20]. Also, the digital ventilator controls respiration based on lung pressure (pressure control method).

The respiration mechanism consists of a mixer chamber, electrical valves (EV), pressure sensors (PS), airflow sensor, vacuum pump, and breathing circuit. The mixer chamber function is to mix the compressor air with oxygen before being supplied to the patient. Inside the mixer chamber, there is also an oxygen sensor beside the PS. Therefore, the pressure and oxygen fraction inside the chamber can be controlled. The electrical valves control the airflow of the mixer chamber and also the lung respiration. The flow rate of inspiration and expiration is measured using the airflow sensor for each inspiration and expiration channel. The inspiration air flow is controlled based on the pressure from the mixer chamber. Meanwhile, there is a vacuum pump at the expiration channel to control the expiration flow.

The controller loT module controls the actuators (EV and vacuum pump) timing based on the measurement from the sensors. The controller loT module respiration information is sent to the cloud storage, which can be accessed via a website application in a mobile gadget or personal computer. Input to the controller also can be sent from the website application, such as the start and stop respiration assistance command. Because of this feature, the developed digital ventilator can be monitored and controlled remotely. The digital ventilator is created using an available component in the market to be easily replicated later. Website application consists of two parts, such as monitoring display and control setting. In the monitoring display, the lung pressure, airflow rate, and tidal volume are shown. In addition, there is also an indicator of mixer chamber pressure and oxygen fraction.

Meanwhile, the control setting comprises respiratory parameters, such as peak pressure (PPeak), positive endexpiratory pressure (PEEP), maximum tidal volume, breath per minute (BPM), and the ratio of inspiration-expiration (IE ratio). Although the pressure control method is adopted, the maximum tidal volume is still necessary for the controller, where it acts as the alarm threshold. Lastly, the respiration assistance can be started using the start-stop button to start and end the respiration assistance.

\subsection{Hardware development}

The respiration mechanism components are shown in Table 1 . The mixer chamber is custom-made with $20 \mathrm{~cm} x$ $30 \mathrm{~cm} \times 20 \mathrm{~cm}$ made from stainless steel, which can stand up to 2 bar air pressure. There are two types of electrical valves, such as solenoid valves and proportional valves. The solenoid valves control the air pressure of the mixer chamber, one for the oxygen inlet and one for the air compressor inlet. The proportional valves are installed at the inspiration and expiration channels. The respiration channel used a proportional valve to regulate the flow rate smoothly. The lung pressure can be controlled nicely with an additional actuator, such as the $14 \mathrm{~V}$ DC vacuum pump with an air debit of 60 SLPM. Sensors used are pressure sensor MPX5010 that measures the lung pressure up to $100 \mathrm{mbar}$,

(c) 2021 The Authors. Published by Universitas Muhammadiyah Malang

This is an open access article under the CC BY SA license. (https://creativecommons.org/licenses/by-sa/4.0/) 
pressure sensor MPX5500 that measures the mixer chamber pressure up to 5 bar, and oxygen sensor KE-25 that measures the mixer chamber fraction oxygen $\left(\mathrm{FiO}_{2}\right)$. There are also air flow sensors that measure the respiration flow rate in each channel up to 70 SLPM. Meanwhile, the breathing circuit is reusable, which is made from silicone material.

There are also supporting components, such as motor drivers, relay, snubber circuit, current rectifier, voltage regulator, and pressure regulator. Motor drivers regulate the current to proportional valves and vacuum pumps, while the relay activates the solenoid valves. The back electromotive force (EMF) caused by the inductive actuators are filtered using a snubber circuit and current rectifier. 12 VDC supplies the digital ventilator. Therefore, there are $3.3 \mathrm{~V}$ and $5 \mathrm{~V}$ voltage regulators to enable the sensors and relay. The pressure regulator restricts the output air pressure from the mixer chamber to 1 bar, so the inspiration pressure does not break the maximum pressure limit of the proportional valves. Figure 2 shows the appearance of the developed digital ventilator from the outside and inside.

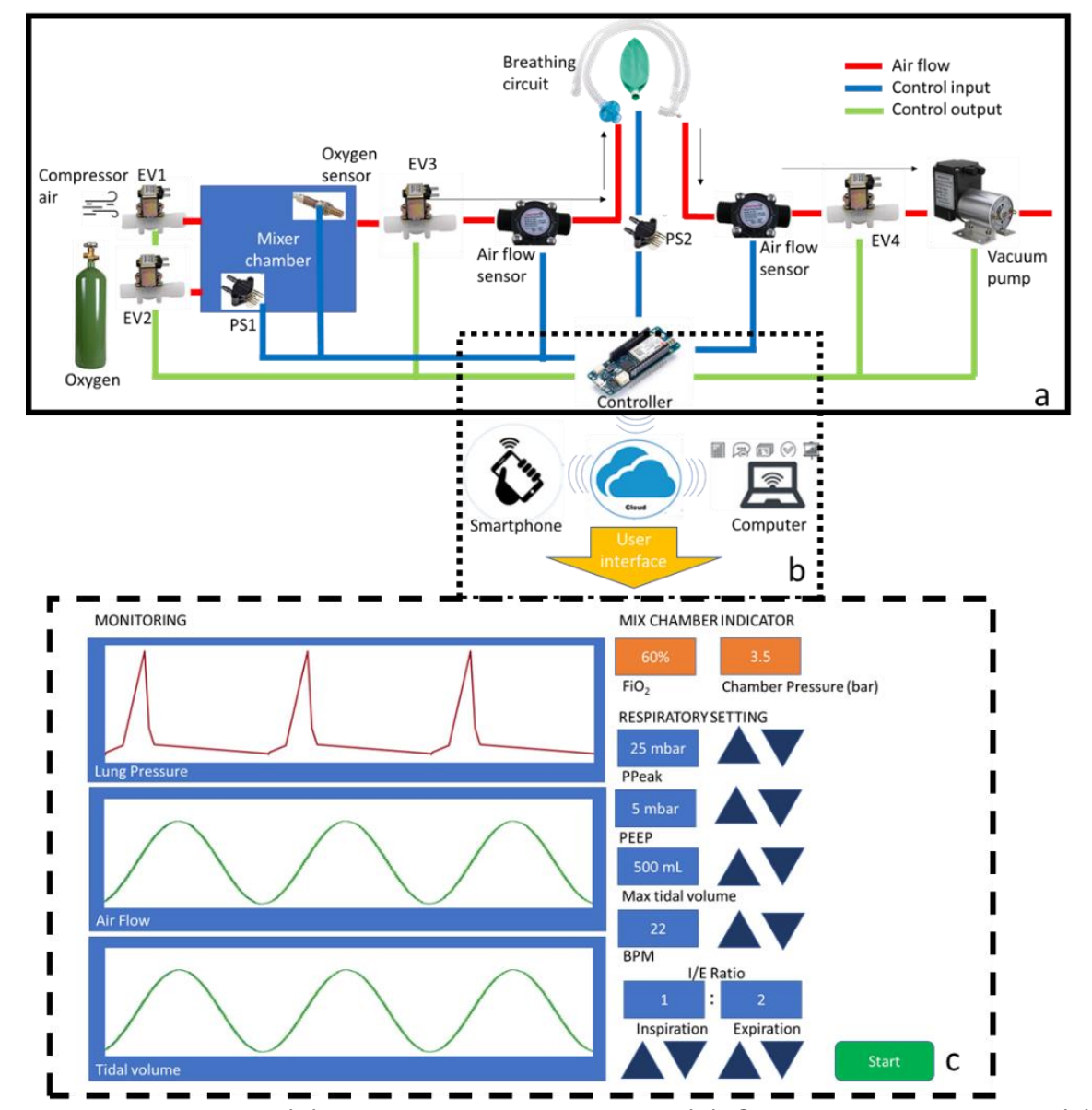

Figure 1. The Digital Ventilator Design: (a) $\bar{R}$ espiration Mechanism, (b) $\bar{C}$ Controller lōT Module, (c) Website Application

Table 1. Respiration Mechanism Components

\begin{tabular}{|c|c|c|c|c|}
\hline No. & Item & Type & Quantity & Specification \\
\hline 1. & Mixer chamber & Custom made & 1 & $\begin{array}{l}\text { Material: Stainless steel } \\
\text { Max pressure: } 2 \text { bar } \\
\text { Inlet: } 2 \text { (6mm tube) } \\
\text { Outlet: } 1 \text { (6mm tube) }\end{array}$ \\
\hline 2 & Solenoid valves & $\begin{array}{c}\text { NPT Pneumatic Solenoid } \\
\text { Valve }\end{array}$ & 2 & $\begin{array}{l}\text { Operating voltage: } 12 \mathrm{VDC} \\
\text { Operating current: } 540 \mathrm{~mA} \\
\text { Power: } 6.5 \text { watt } \\
\text { Inlet-outlet: } 6 \mathrm{~mm} \text { tube }\end{array}$ \\
\hline 3 & Proportional valves & SMC PVQ31-6G-40-01 & 2 & $\begin{array}{l}\text { Type: Normally closed } \\
\text { Operating voltage: } 12 \mathrm{VDC} \\
\text { Current control: } 0 \text { to } 330 \mathrm{~mA} \\
\text { Max pressure: } 1.2 \mathrm{bar} \\
\text { Inlet-outlet: } 6 \mathrm{~mm} \text { tube }\end{array}$ \\
\hline
\end{tabular}

Cite: Adiputra, D., Hafidz, I., Montolalu, B., \& Rasyid, F. (2021). Development of Digital Ventilator with Internet of Things for Preparation of the Next Outbreak in Indonesia. Kinetik: Game Technology, Information System, Computer Network, Computing, Electronics, and Control, 6(3). https://doi.org/10.22219/kinetik.v6i3.1281https://doi.org/10.22219/kinetik.v6i3.1284 
Pressure sensors 1

MPX 5010

5

Pressure sensors 2

MPX 5500

MEMS Flow Sensor

6

Airflow sensor.

D6F-70AB71D-000-0

$7 \quad$ Vacuum pump

Z712-1503-5000

Operating voltage: 5VDC

Signal type: analog

Maximum pressure: $100 \mathrm{mbar}$

Inlet-outlet: $6 \mathrm{~mm}$ tube

Operating voltage: 5VDC

Signal type: analog

Maximum pressure: 5 bar

Inlet-outlet: $6 \mathrm{~mm}$ tube

Operating voltage: 3 to 3.6 VDC

Signal type: digital I2C

Maximum flow rate: 70 SLPM

Inlet-outlet: $6 \mathrm{~mm}$ tube

Power: $32 \mathrm{~W}$

Operating voltage: $12 \mathrm{VDC}$

Maximum suction: 60 SLPM

Vacuum: - $75 \mathrm{kpa}$

Pressure: $150 \mathrm{kpa}$

Material: silicon

$8 \quad$ Breathing circuit Hamilton breathing circuit trap

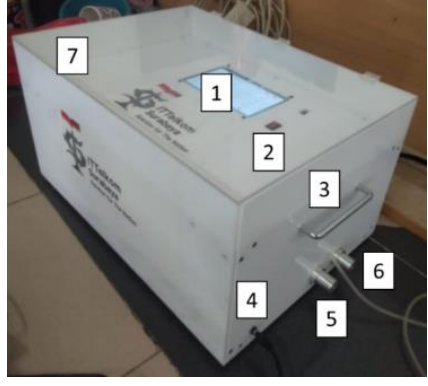

(a)

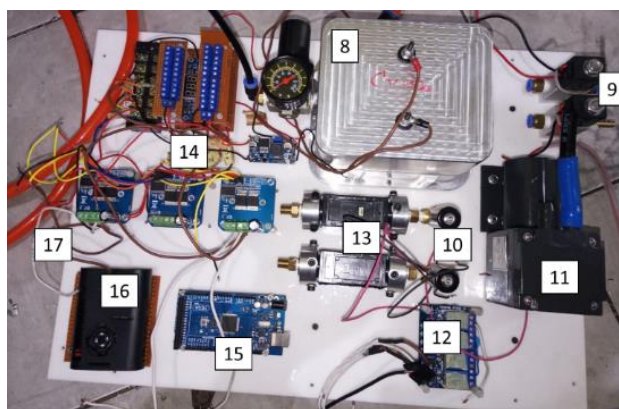

(b)

Figure 2. The Digital Ventilator Appearance Outside (a) and Inside (b): (1) LCD Touchscreen; (2) Power Button; (3) Handle; (4) Power Inlet; (5) Respiration Line; (6) Pressure Line; (7) Cover; (8) Mixer Chamber; (9) Solenoid Valve; (10) Proportional Valve; (11) Vacuum Pump; (12) Relay; (13) Air Flow Sensor; (14) Voltage Driver; (15) Arduino; (16) Raspberry Pi; (17) Pressure Sensor

\subsection{Ventilation Control Algorithm Development}

The control algorithm's purposes are to control the ventilation and to send the data to the cloud. Figure 3 shows the flowchart of the control algorithm. First, raw respiration data are received from the pressure sensors and airflow sensors. Then, the algorithm interprets the data so lung pressure, flow rate, and tidal volume can be displayed both offline in the ventilators monitor and online in the website application. Lung pressure value is obtained by converting the analog signal from the pressure sensor to $\mathrm{cmH}_{2} \mathrm{O}$. The flow rate is displayed in Liter per minute unit, where the value is further processed to obtain the tidal volume in a milliliter. The controller then waits for the "start ventilation" command. If the command says yes, then the controller controls the ventilation and continues displaying the ventilation data. Meanwhile, if the command says no, then the controller stops controlling the ventilation. Instead, the controller checks the power status. If there is still power supplied, then the controller will continue to display the respiration data.

The control of the ventilation process is a finite state machine, as shown in Figure 4. One respiration cycle consists of four states, such as S1, S2, S3, and S4. In S1, the ventilator does the inspiration until the lung pressure equals more than the PPeak. The state moves to $\mathrm{S} 2$, where the respiration is held to maintain the plateau pressure. If the inspiration time is over, then the state moves again to S3. Here, the ventilator does expire, so the lung pressure decreased until the PEEP. In S4, the ventilation is held once again until the expiration time is over. The inspiration time, $I_{t}$ is shown in Equation 1.

$$
I_{t}=\frac{60 I}{B P M(I+E)}
$$

(C) 2021 The Authors. Published by Universitas Muhammadiyah Malang

This is an open access article under the CC BY SA license. (https://creativecommons.org/licenses/by-sa/4.0/) 

and expiration time, $\mathrm{E}_{\mathrm{t}}$ is shown in Equation 2.

$$
E_{t}=\frac{60 E}{B P M(I+E)}
$$

Are calculated based on IE ratio and BPM setting, where $I$ is the inspiration ratio, $E$ is the expiration ratio, and BPM is the breath per minute value. Both $I_{t}$ and $E_{t}$ are calculated in the second unit. Meanwhile, the valve opening is controlled during the inspiration and expiration process.

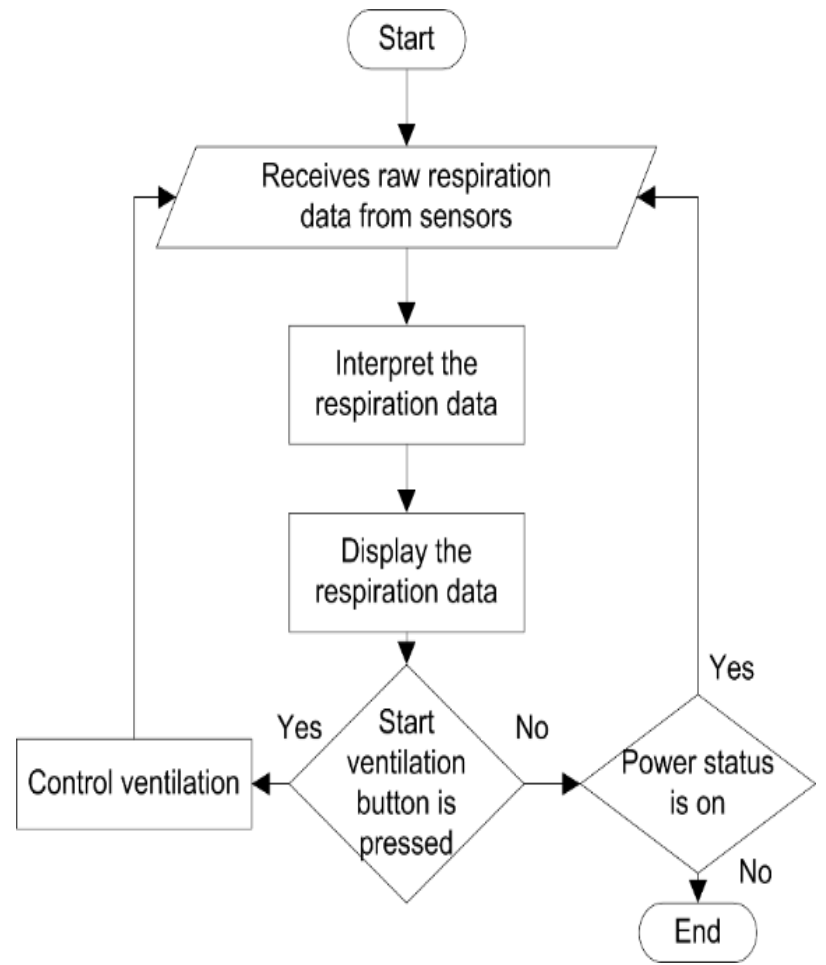

Figure 3. Flowchart Algorithm of the Developed Digital Ventilator

The valve was controlled based on the difference between the current lung pressure and target lung pressure. The proportional valve is fully open until the pressure difference is five mbar. Then, for each one mbar, the valve is closed by half of the previous opening before fully closed on zero mbar pressure difference. Therefore, the valve is open by $50 \%$ when the pressure difference is $4,25 \%$ when the pressure difference is $3 \mathrm{mbar}, 12.5 \%$ when the pressure difference is two mbar, $6.75 \%$ when the pressure difference is one mbar, and $0 \%$ when the pressure difference is 0 mbar. Spike pressure can happen if the proportional valve is fully closed suddenly. Closing the valve step by step avoids the unwanted pressure spike. Meanwhile, the vacuum pump also follows the same rule as the expiration proportional valve during the S3. It started from maximum suction, and then the suction power decreased step by step.

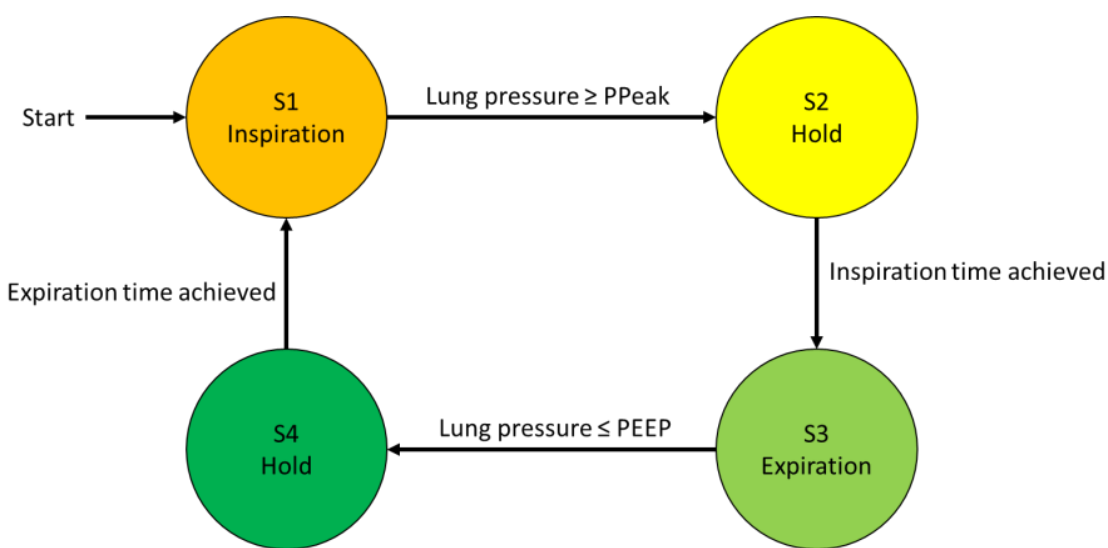

Figure 4. Finite-State Machine Diagram of Ventilation Process Control

Cite: Adiputra, D., Hafidz, I., Montolalu, B., \& Rasyid, F. (2021). Development of Digital Ventilator with Internet of Things for Preparation of the Next Outbreak in Indonesia. Kinetik: Game Technology, Information System, Computer Network, Computing, Electronics, and Control, 6(3). https://doi.org/10.22219/kinetik.v6i3.1281https://doi.org/10.22219/kinetik.v6i3.1284 


\section{4 loT and Website Application Development}

The controller loT module is a combination of Arduino microcontroller and Raspberry Pi. The Arduino collects the data from the sensors (pressure sensors and airflow sensors) and controlling the actuators (valve and pump). The data from sensors are initially floating data types for calculation purposes. The data type was then changed intro string data, sent to the Raspberry Pi via serial communication. The data was arranged in a one-line in print code, where a hashtag separates each data. The information is stored in the raspberry pi memory using MySQL, which the website application can access. Therefore, the digital ventilator can be monitored and controlled by typing the address in the internet browser of any device. The website application is also available in the Raspberry $\mathrm{Pi}$, displayed by a touch screen LCD, so onsite monitoring is possible. Meanwhile, the command from the website application, such as respiratory parameter and start/stop ventilation button, are also received by the Arduino via serial communication. The incoming data is a string data type and translated into float data type for further processing by Arduino.

\subsection{Evaluation and Testing of the Developed Digital Ventilator}

The digital ventilator was tested using a gas flow analyzer provided by Balai Pengamanan Fasilitas Kesehatan (BPFK) Surabaya. The gas flow analyzer did not have a data logger, so manual observation had to be done. BPFK suggested a typical respiration setting of COVID-19 patient condition to evaluate the ventilation control. The setting was PEEP 5, PPeak 20, BPM 15, and I:E ratio of 1:2. A test lung by Macquet was used to simulate the human lung with a maximum capacity of $1 \mathrm{~L}$ air. Figure 5 shows the testing of the digital ventilator using the test lung. On the other hand, the performance of the website application is measured from the response of the ventilation to the website application input command.

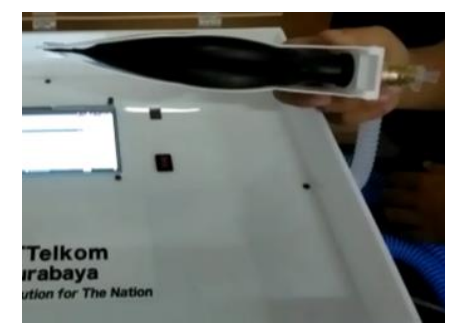

(a)

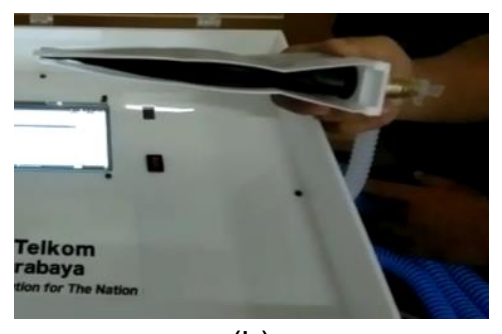

(b)

Figure 5. Digital Ventilator Testing using Test Lung: (a) Test Lung Expanded During Respiration; (b) Test Lung Retracted During Expiration

\section{Results and Discussion \\ 3.1 Respiratory Control}

The lung pressure, airflow, and air volume data when the digital ventilator did the ventilation is shown in Figure 6 and Table 2. From the ten samples, it can be seen that the lung pressure follows the requirement from the respiration setting. The PPeak overshoot during inspiration is $21.82 \pm 1.05 \mathrm{mbar}$, and the PEEP is consistent around 5 mbar, which is $4.73 \pm 0.32$ on average. The BPM and I:E ratio is the most consistent parameter, $16.61 \pm 2.27$ and 1:2.12 \pm 0.08 , respectively. Meanwhile, the airflow measurement of the digital ventilator is not too uniform, which is reflected in the tidal volume measurement. The cause of the inconsistent airflow and volume measurement lies in the fact the code obtains the volume increment by multiplying the measured airflow with the period of each cycle. During the active respiration cycle, the airflow may change and not being recorded, which explains the inaccurate measurement of the tidal volume (the recorded inspiration is only $131.62 \mathrm{ml}$ on average). In this paper, the measured tidal volume is calculated based on a difference of the lowest lung volume and highest lung volume in one cycle, as shown by the double side arrow in Figure 6 . In the future, a Bernoulli equation should be used to obtain the current tidal volume directly based on the lung pressure, but not the volume increment to calculate the tidal volume from time to time. Meanwhile, the developed digital ventilator controls the lung pressure rather than the tidal volume. Therefore, the controller is not affected by the airflow and tidal volume measurement.

Table 2. Respiratory Data Measured by the Digital Ventilator

\begin{tabular}{crrrrr}
\hline Data & $\begin{array}{c}\text { Ppeak } \\
(\mathrm{mbar})\end{array}$ & $\begin{array}{c}\text { PEEP } \\
(\mathrm{mbar})\end{array}$ & BPM & $\begin{array}{c}\text { IE ratio } \\
(1: \mathrm{x})\end{array}$ & $\begin{array}{c}\text { Tidal volume } \\
(\mathrm{mL})\end{array}$ \\
\hline 1 & 23.03 & 4.46 & 22.55 & 2.16 & 158.09 \\
2 & 21.7 & 4.47 & 18.23 & 2.13 & 131.05 \\
3 & 21.59 & 4.75 & 15.87 & 2.17 & 144.55 \\
4 & 20.7 & 4.52 & 16.48 & 2.25 & 143.83 \\
5 & 21.03 & 5.32 & 15.87 & 2.17 & 89.05 \\
\hline
\end{tabular}

(C) 2021 The Authors. Published by Universitas Muhammadiyah Malang

This is an open access article under the CC BY SA license. (https://creativecommons.org/licenses/by-sa/4.0/) 


\begin{tabular}{crrrrr}
\hline 6 & 23.14 & 4.72 & 15.30 & 2.11 & 131.85 \\
7 & 23.03 & 4.78 & 15.58 & 2.05 & 149.11 \\
8 & 21.03 & 4.38 & 15.30 & 1.94 & 146.18 \\
9 & 20.37 & 5.22 & 15.30 & 2.11 & 87.40 \\
10 & 22.58 & 4.69 & 15.58 & 2.05 & 135.18 \\
\hline AVG & 21.82 & 4.73 & 16.61 & 2.11 & 131.62 \\
\hline STD & 1.05 & 0.32 & 2.27 & 0.08 & 24.30 \\
\hline STD\% & 4.81 & 6.70 & 13.66 & 3.98 & 18.46 \\
\hline
\end{tabular}

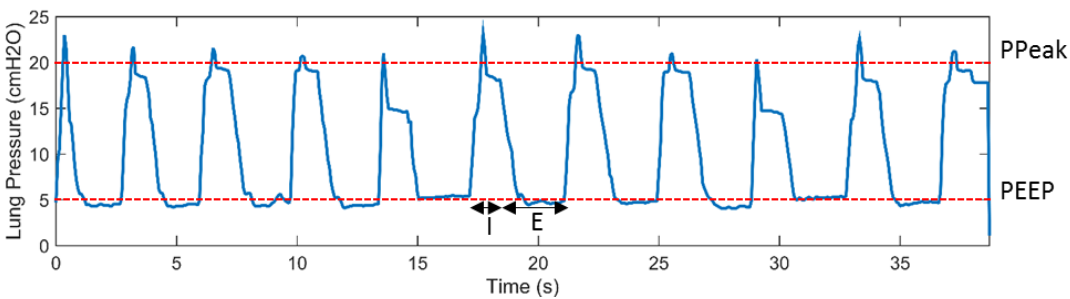

(a)

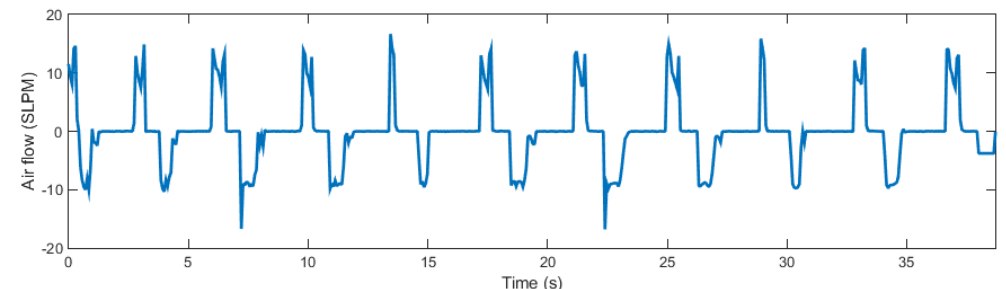

(b)

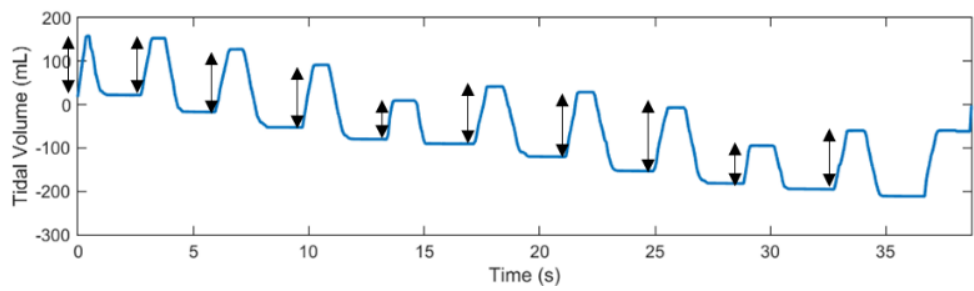

(c)

Figure 6. The Respiratory Data of 10 Cycles of Respiration Measured by the Digital Ventilator: (a) Lung Pressure in $\mathrm{cmH} 2 \mathrm{O}$, (b) Airflow in SLPM, and (c) Tidal Volume in $\mathrm{mL}$

Despite that, the measurement of the ventilation by using the gas flow analyzer at BPFK shows a consistent result. From 10 observations with the settings as mentioned above, the PPeak is $23.17 \pm 2.32$ mbar, PEEP is $4.57 \pm$ 1.03 mbar, BPM is $14.95 \pm 0.05$, I:E ratio is 1:1.97 \pm 0.02 , and tidal volume is $282.77 \pm 33.75 \mathrm{~mL}$, as shown in Table 3 . An example of the measurement data from the gas flow analyzer is shown in Figure 7. Meanwhile, the comparison between average respiratory data measured by digital ventilator and gas flow analyzer is shown in Table 4. The gas flow analyzer data is important because the data says that the developed digital ventilator can produce a consistent result based on the pressure only (standard deviation is around 10\%). The next thing that can be improved is airflow and tidal volume measurement since the error of tidal volume calculation is very large. Therefore, controlling the ventilation accurately, the digital ventilator also provides information clearly to the user. In this case, the target user is the doctor who monitors the patient respiratory remotely.

Table 3. Respiratory Data Measured by the Gas Flow Analyzer

\begin{tabular}{cccccc}
\hline Data & $\begin{array}{c}\text { Ppeak } \\
(\mathrm{mbar})\end{array}$ & $\begin{array}{c}\text { PEEP } \\
(\mathrm{mbar})\end{array}$ & BPM & $\begin{array}{c}\text { IE ratio } \\
(1: \mathrm{x})\end{array}$ & $\begin{array}{c}\text { Tidal volume } \\
(\mathrm{mL})\end{array}$ \\
\hline 1 & 26.3 & 5 & 15 & 1.99 & 323.8 \\
2 & 21 & 4.8 & 14.9 & 1.98 & 264 \\
3 & 21.5 & 2.8 & 15 & 1.94 & 261.7 \\
4 & 25.3 & 5.8 & 15 & 1.97 & 317.3 \\
5 & 21.8 & 5.1 & 14.9 & 1.98 & 258.3 \\
6 & 25.9 & 3.4 & 14.9 & 1.96 & 323.6 \\
\hline
\end{tabular}

Cite: Adiputra, D., Hafidz, I., Montolalu, B., \& Rasyid, F. (2021). Development of Digital Ventilator with Internet of Things for Preparation of the Next Outbreak in Indonesia. Kinetik: Game Technology, Information System, Computer Network, Computing, Electronics, and Control, 6(3). https://doi.org/10.22219/kinetik.v6i3.1281https://doi.org/10.22219/kinetik.v6i3.1284 


\begin{tabular}{cccccc}
\hline 7 & 21.1 & 5.1 & 14.9 & 1.95 & 249.9 \\
8 & 21.4 & 3.2 & 15 & 1.97 & 252.8 \\
9 & 25.9 & 5.2 & 15 & 1.94 & 321.9 \\
10 & 21.5 & 5.3 & 14.9 & 1.98 & 254.4 \\
\hline AVG & 23.17 & 4.57 & 15 & 1.966 & 282.77 \\
\hline STD & 2.33 & 1.03 & 0.05 & 0.02 & 33.75 \\
\hline STD\% & 10.05 & 22.62 & 0.35 & 0.90 & 11.94 \\
\hline
\end{tabular}

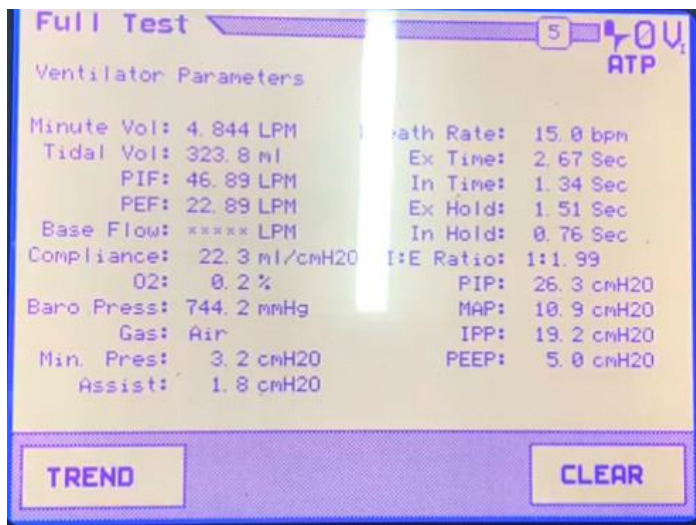

Figure 7. Sample of Respiration Data Obtained from the Gas Flow Analyzer

Table 4. Respiratory Data Comparison of Digital Ventilator and Gas Flow Analyzer

\begin{tabular}{cccccc}
\hline & $\begin{array}{c}\text { Ppeak } \\
(\mathrm{mbar})\end{array}$ & $\begin{array}{c}\text { PEEP } \\
(\mathrm{mbar})\end{array}$ & $\mathrm{BPM}$ & $\begin{array}{c}\mathrm{IE} \text { ratio } \\
(1: \mathrm{x})\end{array}$ & $\begin{array}{c}\text { Tidal volume } \\
(\mathrm{mL})\end{array}$ \\
\hline Digital ventilator & 21.82 & 4.73 & 16.61 & 2.11 & 131.62 \\
Gas Flow Analyzer & 23.17 & 4.57 & 14.95 & 1.966 & 282.77 \\
Absolute error & 1.35 & 0.16 & 1.66 & 0.144 & 151.15 \\
\hline
\end{tabular}

\subsection{Online Control and Monitoring}

Figure 8 shows the website application. First, the website displayed the room number, such as Mawar 1, Mawar 2, and Mawar 3. Then, if a room is chosen, the website application will show the bed number. The room and bed number can be adjusted accordingly to the real situation at the hospital, for instance. The website application then offers the digital ventilator monitoring dashboard of the corresponding bed. The lung pressure (PAW) is displayed in the range of -20 to 60 mbar. The airflow is displayed in the range of -100 to 100 standard liters per minute. The tidal volume is shown in the range of -20 to $1000 \mathrm{~mL}$. The chamber pressure (CP) is displayed in the bar unit. Meanwhile, the oxygen fraction is expressed in the percentage. The dashboard also has an input interface. The Ppeak is displayed in mbar unit, which can be adjusted by a unit of one. Available PEEP settings are $0,5,10$, and 15 mbar. The maximum BPM is set to be 30, which can also be adjusted by one unit. I:E ratio can be chosen between the two options, such as 1:2 and 1:3. The tidal volume can be set to a maximum of $800 \mathrm{~mL}$ by a unit of $50 \mathrm{~mL}$. Lastly, the start/stop button is available at the bottom left. If the start button is pressed, then the digital ventilator starts the ventilation. If the stop button is pressed, then the digital ventilator stops the ventilation. The button is the only one where it changes appearance when being pressed. For instance, the button shows the "start" button when the respiration is stopped and vice versa. The digital ventilator average response to input of the website application can be seen in Table 5. The time response is fast enough, with an average time of $0.23 \mathrm{~s}$. Based on the result, it is safe to assume that the developed website application can control the digital ventilator well from a far distance.

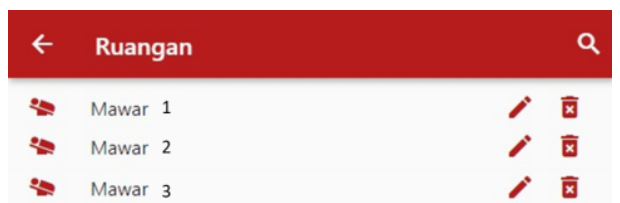

(a)

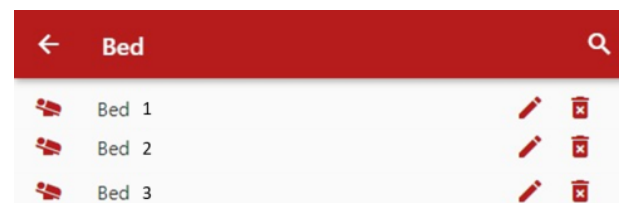

(b)

(c) 2021 The Authors. Published by Universitas Muhammadiyah Malang

This is an open access article under the CC BY SA license. (https://creativecommons.org/licenses/by-sa/4.0/) 


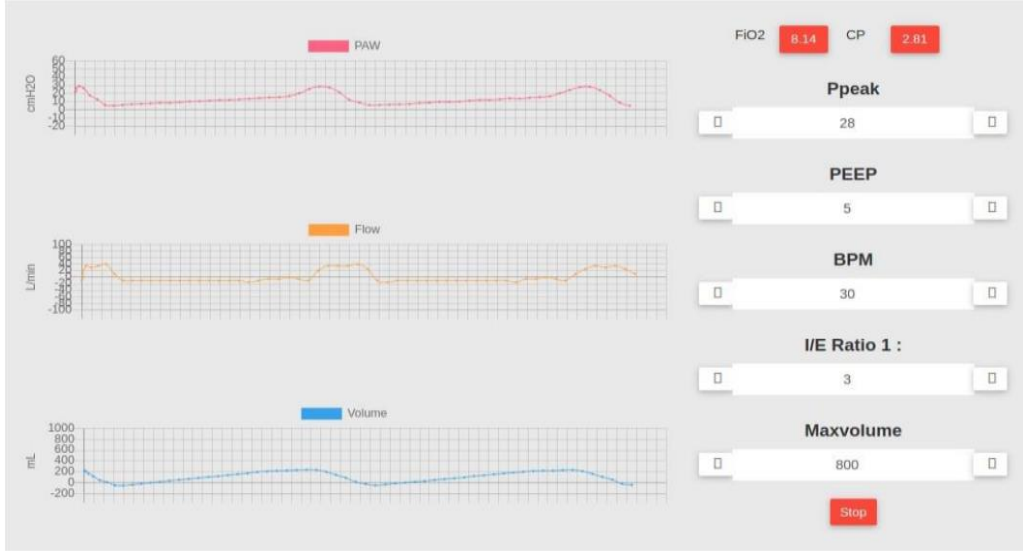

(c)

Figure 8. The Digital Ventilator Website Application: (a) Room Selection; (b) Bed Selection; (c) dashboard Monitoring

Table 5. Input Button Response of the Web Application to the Digital Ventilator

\begin{tabular}{cccccccccccc}
\hline & \multicolumn{1}{c}{ Trial $(\mathrm{s})$} & \multicolumn{1}{c}{ Average } \\
& 1 & 2 & 3 & 4 & 5 & 6 & 7 & 8 & 9 & 10 & $(\mathrm{~s})$ \\
\hline Response time & 0.266 & 0.21 & 0.282 & 0.268 & 0.21 & 0.248 & 0.206 & 0.214 & 0.242 & 0.282 & 0.2434 \\
\hline
\end{tabular}

Therefore, if the digital ventilator developed in this study is implemented in the hospital, the doctor can monitor patient ventilation from his own room. In case of different setting is necessary after seeing the monitored ventilation, then the doctor can also change the ventilation setting easily and remotely. This type of technology, the ventilator with loT feature is not common in Indonesia. Several ventilators with loT have been reported in Indonesia local news, such as ventilator developed by Universitas PGRI Semarang [21] and Universitas Gunadarma [22]. The reported ventilators had additional camera instead of respiratory sensor only, thus by standing in front of the camera, the doctor can also see the patient's condition. However, the application is restricted to only one ventilator. Meanwhile, the digital ventilator presented in this study offered a website application that can monitor and control several ventilators on demand. Fast forward, the application of the developed digital ventilator can also reach patient homes instead of hospital rooms only.

\section{Conclusion}

In this paper, the development of a digital ventilator is presented. The digital ventilator is comprised of three main parts, such as respiration mechanism (I), controller loT module (II), and website application (III). The components are available in the market so that a digital ventilator can be made affordably. The developed digital ventilator has been tested by comparing the respiratory data with the gas flow analyzer from BPFK as the gold standard. The result shows that the developed digital ventilator can produce a consistent result based on the pressure only (standard deviation is around $10 \%$ ). The absolute PPeak error is $1.35 \mathrm{mbar}$, the PEEP error is $0.16 \mathrm{mbar}$, the BPM error is 1.66 , and I:E ratio error is 0.144 . The absolute error result shows that the digital ventilator successfully controls respiration based on lung pressure (pressure control ventilation). However, in terms of tidal volume, the absolute error is significant, which is $151.15 \mathrm{~mL}$. Therefore, an improvement in the measurement of airflow and tidal volume should be made in the future. Thus, controlling the ventilation accurately, the digital ventilator also provides information clearly to the user. In this case, the target user is the doctor who monitors the patient respiratory remotely. Lastly, the performance of the website application is measured based on the response time of the digital ventilator to the input command. The average time response is $0.23 \mathrm{~s}$. It is safe to assume that the doctor can use the website application to control the digital ventilator well from a far distance.

\section{Acknowledgment}

The authors would like to express their gratitude to Telkom Direktorat Digital Business (DDB) and Institut Teknologi Telkom Surabaya for their financial support in this research. Appreciation is also addressed to Balai Pengaman Fasilitas Kesehatan (BPFK) Surabaya for their help in providing the gas flow analyzer.

\section{References}

[1] A. Faricha, M. Achirul Nanda, S. Maghfirotul Ulyah, matut Tamimah, E. Indasyah, and R. Addwiyansyah Alvaro Samrat, "The Comparative Study for Predicting Disease Outbreak," Journal of Computer, Electronic, and Telecommunication, vol. 1, no. 1, 2020. https://doi.org/10.52435/complete.v1i1.48

[2] Zhou, L., Liu, H.G. "Early Detection and Disease Assessment of Patients With Novel Coronavirus Pneumonia". National Library of medicine, 43 (3), 167-170, 2020. https://doi.org/10.3760/cma.j.issn.1001-0939.2020.0003

Cite: Adiputra, D., Hafidz, I., Montolalu, B., \& Rasyid, F. (2021). Development of Digital Ventilator with Internet of Things for Preparation of the Next Outbreak in Indonesia. Kinetik: Game Technology, Information System, Computer Network, Computing, Electronics, and Control, 6(3). https://doi.org/10.22219/kinetik.v6i3.1281 https://doi.org/10.22219/kinetik.v6i3.1284 
[3] Chen N, Zhou M, Dong X, Qu J, Gong F, Han Y et al. Epidemiological and clinical characteristics of 99 cases of 2019 novel coronavirus pneumonia in Wuhan, China: a descriptive study. Lancet. 2020;395(10223):507-513. https://doi.org/10.1016/S0140-6736(20)30211-7

[4] World Health Organization, Coronavirus disease 2019 (COVID-19) Situation Report 46, 2020.

[5] Sohrabi C, Alsafi Z, O'Neill N, Khan M, Kerwan A, Al-Jabir A, et al. World Health Organization declares global emergency: A review of the 2019 novel coronavirus (COVID-19). Int J Surg. 2020;76:71-76. https://doi.org/10.1016/j.ijsu.2020.02.034

[6] A. D. Fakhira, A. S. Pawitra, K. C. Diyanah, E. A. Wikurendra, I. Nagy, and N. S. M. Abdeljawad, "Awareness of Doing 3M (Wearing Mask, Physical Distancing, Washing Hands) During Pandemic Era in Rural and Urban Families," JURNAL KESEHATAN LINGKUNGAN, vol. 13, no. 2, p. 94, Apr. 2021. http://dx.doi.org/10.20473/jkl.v13i2.2021.94-101

[7] "Positif Covid-19 Harian Kembali Pecah Rekor 14.518 Kasus," CNN Indonesia, 2021.

[8] Suwarsono, Budiono, W. Denny, Kuncoro, U. AC, and F. MN, "Desain Mekanik Untuk Ventilator Sistem Kendali Adaptif," 2020.

[9] S. Hidayat et al., "Lessons learned from rapid development of CPAP ventilator vent-i during COVID-19 pandemic in Indonesia," Journal of Engineering and Technological Sciences, vol. 52, no. 5, pp. 765-778, 2020. https://doi.org/10.5614/j.eng.technol.sci.2020.52.5.11

[10] G. Gusti, "Sri Sultan Apresiasi Ventilator Karya Peneliti UGM," Universitas Gadjah Mada, Jul. 07, 2020.

[11] adminits, "E-VITS Ventilator Declared to Have Passed the BPFK Technical Feasibility Test," ITS news, 2020.

[12] "e-Learning_Ventilation modes ABC," Hamilton Medical, 2018.

[13] P. Gloria Setyvani, "Kematian Meningkat, Dokter Berusaha Tak Pakai Ventilator untuk Covid-19," Kompas, 2020.

[14] U.K. Medicines \& Healthcare products Regulatory Agency, "Rapidly manufactured ventilator system," Apr. 2020.

[15] Grainger College of Engineering, "Illinois RapidVent," Mar. 2020.

[16] E. L'Her and A. Roy, "Bench tests of simple, handy ventilators for pandemics: Performance, autonomy, and ergonomy," Respiratory Care, vol. 56, no. 6, pp. 751-760, 2011. https://doi.org/10.4187/respcare.00841

[17] E. L'Her, A. Roy, and N. Marjanovic, "Bench-test comparison of 26 emergency and transport ventilators," Crit Care, vol. 18, 2014, Art. no. 506. https://dx.doi.org/10.1186\%2Fs13054-014-0506-0

[18] M. Ndiaye, S. S. Oyewobi, A. M. Abu-Mahfouz, G. P. Hancke, A. M. Kurien and K. Djouani, "loT in the Wake of COVID-19: A Survey on Contributions, Challenges and Evolution," in IEEE Access, vol. 8, pp. 186821-186839, 2020. https://doi.org/10.1109/ACCESS.2020.3030090

[19] Hidayat, J. Saiful, S. Iman, Suprapto, I. Aidil, and S. Eddy, "Design and Implementation of Ventilator for Breathing Apparatus," in IOP Conference Series: Materials Science and Engineering, Dec. 2020, vol. 990, no. 1. https://doi.org/10.1088/1757-899X/990/1/012007

[20] C. Galbiati et al., "Mechanical Ventilator Milano (MVM): A Novel Mechanical Ventilator Designed for Mass Scale Production in Response to the COVID-19 Pandemic," Mar. 2020.

[21] K. Jateng, "Kreatif dan Inovatif Ventilator Berbasis IOT," KompasTV, 2020.

[22] A. Laraspati, "Salut! Sekelompok Mahasiswa Kembangkan Ventilator Berbasis loT aja !," detikNews, 2020. 